Sylwester Zielka

https://doi.org/10.26881/pwe.2019.47.10

ORCID: 0000-0001-8406-7429

Uniwersytet Gdański

pedsz@ug.edu.pl

\title{
Niereligijni rodzice wobec instytucji szkoły
}

\section{Summary}

\section{Non-religious parents versus educational institutions}

The purpose of the paper is to identify and analyse problems reported by non-religious parents. These parents are subjects of the education process whose children attend Polish educational (usually public) institutions, in which religion is one of the elements of the curriculum. The study is guided by the assumption that such a situation may lead to various tensions and conflicts, the expression of which can be found on the Internet as a space for communication and search for solutions. The research presented in this paper is of an exploratory nature. It includes content analysis of posts posted on one of the Facebook social networking groups. Analysed statements of non-religious parents indicate that pre-schools and primary schools are to a large extent institutions strongly connected with declared religious values, which also leads to a negative perception of non-religious parents and their children.

Keywords: nonreligiousness, religious education, parents, support

Słowa kluczowe: niereligijność, edukacja religijna, rodzice, wsparcie

Istnienie edukacji religijnej w polskich szkołach uznawane jest raczej za fakt niż za kwestię, wobec której podmioty lub grupy społeczne mogą zgłaszać zastrzeżenia i kierować krytyczne uwagi. Niemniej edukacja religijna nie obejmuje wszystkich dzieci w polskich szkołach, są bowiem wśród nich takie, których rodzice nie wyznają religijnego światopoglądu. W artykule tym koncentruję się na sposobach opisywania przez niereligijnych rodziców trudności, z jakimi spotykają się ze strony szkół, do których uczęszczają ich dzieci, oraz na strategiach radzenia sobie z tymi trudnościami. Choć istnieją różne perspektywy omawiające funkcjonowanie szkoły i przedszkola, na potrzeby tego tekstu przyglądam się im jako instytucjom, w których programie obecne są zajęcia z religii i w których, w wielu wypadkach, są prowadzone praktyki religijne inne niż lekcje religii. Aby poznać te sposoby i strategie, zbadałem wypowiedzi uczestników internetowej grupy dyskusyjnej o nazwie Nasze dzieci nie chodzą na religię.

W naukach społecznych dominuje trend badań nad religią i religijnością jako społecznymi fenomenami, dotyczy on badań nad ich przemianami, odmianami, uwarunkowaniami etc. W zdecydowanie w mniejszym stopniu są prowadzone badania społeczne, w tym 
pedagogiczne, dotyczące osób bądź grup niereligijnych (Tyrała 2014). Warto więc tę lukę systematycznie wypełniać, by poznać możliwie szeroki obraz społeczeństwa i edukacji. Realizując ten cel, najpierw rozpatrzyłem niereligijność jako problem społeczny oraz kontekst prawny obecności lekcji religii w szkole, po czym przeszedłem do opisu metodologii przeprowadzonych badań i opisałem wyniki badań dotyczące trudności, z którymi mierzą się niereligijni rodzice, i sposoby radzenia sobie z tymi trudnościami.

Choć współcześnie nadal trwają gorące spory filozofów, teologów i badaczy społecznych o określenie tego, czym jest religia (np. Hervieu-Léger 2007), należy uznać ją za fakt społeczny. Oznacza to, że pełni ona znaczącą funkcję zarówno w życiu jednostkowym, jak i społecznym, ponieważ dostarcza rozpoznawalnego uniwersum symbolicznego przedstawicielom danej kultury. W miarę instytucjonalizowania się sposobów wyrażania połączeń między sacrum i profanum (Eliade 2000) w wielu społeczeństwach tradycyjnych (o ile nie we wszystkich) religia stała się ,,świętym baldachimem”, czyli podstawowym wymiarem wyjaśniania i usprawiedliwiania porządków społecznych, który może obejmować wszystkie subsystemy życia społecznego. Natomiast wraz z nadejściem nowoczesności nastąpiła pluralizacja wyjaśnień i uzasadnień życia społecznego i religia utraciła swoją oczywistą moc eksplanacyjną - to przyczyniło się z jednej strony do „prywatyzacji” wyjaśnień (np. przez naukę), z drugiej zaś do ,prywatyzacji” samej religii (Berger 2005).

Wydaje się jednak, że nadal, przynajmniej w Polsce, dominującym sposobem określania relacji człowieka względem religii jest ujmowanie go jako istoty ze swej „natury” wierzącej, doświadczającej sacrum - co jest istotą religii (Wach 1961: 44) - czy po prostu religijnej: homo religiosus (Eliade 1997: 1). Co więcej, przekonanie to na gruncie polskim jest pozytywnie skorelowane z obowiązującą tożsamością narodową, więc zwrot „Polak-katolik” jest nagminnie używane jako określenie wcale nie stereotypowe, lecz jako termin rzekomo oddający ogólne tendencje religijne społeczeństwa (Obirek 2015: 247-320).

Pomimo dokonujących się również w społeczeństwie polskim procesów sekularyzacji (Grabowska 2018) dominuje przekonanie, które określam jako imperatyw wiary. Oznacza to, że społeczne postrzeganie i wyobrażanie drugiego człowieka milcząco zakłada, że jest on człowiekiem wierzącym i regulującym swoje praktyki życiowe podług wymagań religijnego credo, sama religia zaś jawi się jako najbardziej oczywista przestrzeń definiowania i określania własnej tożsamości, tak też jest przedstawiana przez jej przedstawicieli. Trawestując słowa Petera Ludwiga Bergera, ,święty baldachim” religii okrywa rzeczywistość polską tak szczelnie, że niemal nic innego nie można spod niego zobaczyć. Dlatego też dostrzeżenie, że w społeczeństwie polskim osoby niereligijne, w tym ateiści i agnostycy, są zwykłymi uczestnikami życia społecznego, nastręcza ich przeciwnikom (np. Sochoń 1999: 198; Zwoliński 2018: 18) niemałych trudności poznawczych i etycznych. Tymczasem osoby niereligijne biorą udział we wszystkich tych samych obszarach społecznych doświadczeń i sytuacji społecznych, w jakich są obecne osoby religijne (Blackford, Schüklenk 2014), z tą różnicą, że religia bądź religijność nie ma dla nich żadnego znaczenia poza tym, które jest im oferowane lub narzucane. Jeśli więc w jakimś 
obszarze życia społecznego przypisuje się religii ważne znaczenie ${ }^{1}$, to należy zapytać, co z ludźmi, którzy tych przekonań nie podzielają, i jak to się ma do zasady równości i poszanowania godności. Jednym z takich obszarów jest szkoła i obecne w niej różnorodne praktyki religijne.

Na mocy instrukcji Ministra Edukacji Narodowej z 30 sierpnia 1990 r. do publicznych przedszkoli i szkół został wprowadzony przedmiot o nazwie religia. Przedmiot ten ma charakter konfesyjny (wyznaniowy), a nie religioznawczy, co oznacza, że każdy przedszkolak i uczeń uczestniczący w tych zajęciach poznaje zasady własnej religii, a przede wszystkim przedmiot ten ma „budzić” wiarę i nawiązywać więź z danym Kościołem, co w odniesieniu do polskich warunków oznacza dominację przekazu zasad religii rzymskokatolickiej.

Znaczącą cechą opisanego imperatywu wiary jest również to, że wiele aktów prawnych reguluje życie społeczne i indywidualne w jego religijnym wymiarze. W interesującym mnie kontekście są to przede wszystkim: Konstytucja RP z 1997 r., Konkordat między Stolicą Apostolską a i Rzeczpospolitą Polską z 1993 r. oraz Ustawa z dnia 7 września 1991 r. o systemie oświaty (z późniejszymi zmianami w postaci rozporządzeń Ministra Edukacji Narodowej). Szkoła publiczna z jednej strony nie jest nigdzie określona jako instytucja świecka, ponieważ konstytucja nie wprowadza zasady świeckości państwa, lecz zasadę neutralności światopoglądowej, z drugiej zaś szkoły nie są zależne od kościołów i związków wyznaniowych, a jednocześnie powinny być otwarte i przyjazne w stosunku do każdego ucznia bez względu na jego wyznanie czy światopogląd. Z kolei konkordat, który wskazuje na zasadę niezależności i autonomii Kościoła i państwa (a zatem rozdział Kościoła od państwa), jednocześnie zobowiązuje państwo, zatem odpowiednio: przedszkola i szkoły publiczne, do umożliwienia kościołom i związkom wyznaniowym o uregulowanej sytuacji prawnej nauczania religii pod postacią przedmiotu szkolnego, jeśli zostanie zgłoszona taka prośba przez rodziców bądź ucznia. Zasady te znajdują swoje zastosowanie i rozwinięcie w obowiązującym prawie oświatowym, które reguluje szczegółowe zapisy w kwestii m.in. uczestnictwa w lekcjach religii lub w nich nieuczestniczenia. Zajęcia te mają zatem charakter nadobowiązkowy w stosunku do pozostałych zajęć szkolnych i mają - przynajmniej w założeniu - podobny status jak jakiekolwiek funkcjonujące w szkole kółko zainteresowań. Obecność lekcji religii i innych wydarzeń o religijnym charakterze w polskiej szkole nie jest jednak kwestią niebudzącą kontrowersji i wątpliwości. Jedną z grup, które wyrażają swój sprzeciw wobec przyjęcia takich rozwiązań, są niereligijni rodzice.

Anna Babicka-Wirkus zauważa, że: „Rodzice stanowią ważny element rzeczywistości szkolnej, który jest często pomijany w jej opisach, stwarzając tym samym pozór nieistnienia lub marginalnego funkcjonowania rodziców w tej przestrzeni. Tymczasem rodzice odgrywają ważną rolę w tworzeniu kultury szkoły, która w dużej mierze zależy od rodzaju i jakości zaangażowania się dorosłych w formalny proces kształcenia ich dzieci” (Babicka-Wirkus 2019: 221-222). Nieuwzględnianie rodziców jako ważnej i osobnej kategorii

1 Na temat znaczenia religii w życiu Polaków zob. np. Boguszewski (2012). 
może prowadzić do powstawania zubożonego, a tym samym fałszywego obrazu funkcjonowania podmiotów okołoszkolnych. $\mathrm{W}$ tym kontekście należy zatem uznać rodziców za ważnych aktorów okołoszkolnych, którzy z różnych powodów mogą odczuwać dyskomfort wobec działań realizowanych w szkole i jej otoczeniu (społecznym, ekonomicznym, politycznym czy ideologicznym), a także to poczucie dyskomfortu zamieniać na realne działania przez uczestnictwo w życiu szkoły lub jeśli nie jest to możliwe - przez inne ośrodki, w tym media i Internet, i przez reagowanie na dziejące się w szkole wydarzenia (Mendel 2000).

Prezentowane tutaj dane są poświęcone sposobom opisywania doświadczeń rodziców w kontakcie z instytucją szkoły jako przestrzenią praktyk religijnych, do których zalicza się zarówno lekcje religii, jak i inne formy religijnych rytuałów, odbywające się w szkole jako przestrzeni publicznej. Podstawową techniką zastosowaną w celu analizy tego problemu jest jakościowa analiza treści wypowiedzi umieszczonych w postach internetowych. Oznacza to, że analizie poddano tylko treść postów, bez uwzględniania ich dodatkowej zawartości (np. wielkości liter, materiałów wizualnych, treści odnośników) oraz komentarzy do postów. Założono, że dodatkowa zawartość współgra z treścią posta i najwyżej wzmacnia funkcję poznawczą i ekspresyjną wypowiedzi; komentarze natomiast mają charakter wtórny wobec podstawowej wypowiedzi i są przez nią wywołane.

Jednostką analizy uczyniono treść poszczególnego posta (wpisu). Ponieważ celem analizy jest ukazanie problemów w relacji niereligijnych rodziców do szkoły, ujawniających się w ich wypowiedziach, zasadne wydaje się, by w celu utworzenia listy takich tematów tę właśnie jednostkę potraktować jako zasadniczy tekst, do którego odnosi się analiza, tym bardziej że badania jakościowe dążą do uchwycenia sensów wytwarzanych przez aktorów społecznych, a zrozumienie sensu zakłada całościowe spojrzenie na badany tekst. W tym kontekście Tomasz Piekot (2006) pisze, że aby odpowiedzieć sobie na pytanie: o czym są te teksty?, badacz powinien założyć możliwość uchwycenia ,sensu globalnego", czyli tekstu jako całości. Zatem redukcja jednostki do poszczególnych słów kluczy (jak czyni się to w ilościowej analizie treści) nie przyniosłaby pożądanego rezultatu. Tym samym klucz kategoryzacyjny jest $\mathrm{w}$ badaniach jakościowych efektem wielokrotnego czytania tekstów, w tym wypadku postów, aby wyłonić powtarzalność określonych przez materiał empiryczny kategorii tematycznych przy zachowaniu ich różnorodności. Jest to postępowanie indukcyjne, które zakłada rozwój wiedzy badacza w trakcie prowadzenia postępowania badawczego.

Autorami badanych przeze mnie wypowiedzi są rodzice, którzy należą do grupy Nasze dzieci nie chodzą na religię. Jest to grupa zamknięta, skupiająca użytkowników Facebooka (6436 członków, stan na 31.03.2019 r.). Członkowie tej grupy to rodzice, „których dzieci nie chodzą na religię i dla zwolenników świeckiej szkoły”, choć umieszczane są także posty o tematyce okołoszkolnej. Zasięg tej grupy jest zatem bardzo szeroki (ogólnopolski, ale zdarzają się również posty i komentarze osób z zagranicy). Do badania wybrałem wypowiedzi rodziców dzieci uczęszczających do przedszkola i szkoły podstawowej. W sumie zebrałem 231 postów w okresie między 1 września a 30 listopada 2018 r., 
które włączyłem do dalszej analizy. Początek badania i analizy wyznaczył początek roku szkolnego, wtedy też następuje intensyfikacja umieszczania postów opisujących problemy niereligijnych rodziców, jego zaś zakończenie nastąpiło w momencie zauważalnej powtarzalności pojawiających się wątków tematycznych. Po zakończonych badaniach zwróciłem się do wybranych rodziców o możliwość umieszczenia ich wypowiedzi w tym opracowaniu jako egzemplarycznych dla danej kategorii.

W swoich badaniach starałem się, po pierwsze, określić, jakie najczęściej trudności lub grupy trudności opisują rodzice, którzy nie są zainteresowani uczestnictwem ich dzieci na lekcjach religii, oraz czy ich wypowiedzi wskazują na uporczywość tych trudności czy raczej na ich przejściowy charakter. Drugie pytanie badawcze dotyczyło sposobów (strategii) radzenia sobie z napotykanymi trudnościami oraz roli, jaką odgrywa grupa, na której są umieszczane analizowane posty. Odpowiadając na pierwsze pytanie badawcze, wyodrębniłem sześć kategorii, które określają wypowiedzi o trudnościach rodziców z religią w placówkach edukacyjnych ich dzieci.

Kategoria pierwsza: hegemonia religijna ponad prawem. Kategoria ta opisuje wypowiedzi zwracające uwagę na nagminne łamanie przepisów przez dyrektorów szkół i podległych im nauczycieli w sprawie deklaracji uczestnictwa dzieci w lekcjach religii. Obowiązujące przepisy wyraźnie wskazują, że rodzice dzieci niepełnoletnich składają deklarację o uczęszczaniu na lekcję religii lub etyki. Tymczasem rodzice w badanych wypowiedziach ujawniają, że dyrekcja i nauczyciele postępują odwrotnie - żąda się deklaracji nieuczenia od rodziców dzieci nieuczęszczających, a w najlepszym wypadku taką deklarację rozdaje się do wypełnienia wszystkim rodzicom, co sprawia, że przedmiot, który jest nieobowiązkowy (według prawa ma taki sam status jak kółko szachowe lub sportowe), zyskuje inny - specjalny, wyższy - status. Plan lekcji, który jest ogłaszany we wrześniu, obejmuje wszystkie dzieci, zarówno te, które będą, jak i te, które nie będą uczęszczały na lekcje religii - istnieje zatem domniemanie, że nie znajdą się dzieci z tej drugiej kategorii, nie będzie „odstępców”. Stosowana jest tu silna forma presji społecznej. Oto przykłady:

„Dzień dobry. Proszę o pisemną deklarację rezygnacji z uczęszczania córki na religię. Prawdopodobnie w zeszłym roku szkolnym taka deklaracja była przekazana księdzu ale w tej chwili przejęłam klasę i nie mam kontaktu z księdzem dlatego proszę o dostarczenie takiego pisma przez dziecko do mnie lub wychowawcy klasy". Taki liścik dostałam na librusie. Dzięki Wam, droga Grupo, ręce nie opadły mi aż do podłogi ${ }^{2}(\mathrm{R}, 1,1)$.

I kolejny wkurw dzisiejszego dnia. Starszy przyniósł deklaracje na rele i etyke. Nie oddajemy nic. Czekam na wezwanie $(\mathrm{R}, 1,5)$.

Kategoria druga: w poszukiwaniu przechowalni dla dzieci. Kolejnym opisywanym w badanych wypowiedziach rodziców problemem jest zapewnienie sposobu spędzania czasu przez ich dzieci w trakcie trwania lekcji religii (głównie w przedszkolu i w szkole

2 Zachowuję pisownię oryginalną we wszystkich analizowanych wypowiedziach. 
podstawowej). Według przepisów prawa lekcje religii (dwie godziny tygodniowo w szkole podstawowej) powinny być pierwszą lub ostatnią lekcją w danym dniu. Często jednak tak nie jest. Wówczas dziecko, które nie uczestniczy w takich lekcjach, spędza czas na korytarzu, przebywa w świetlicy, bibliotece, jest oddawane pod opiekę sekretarki, bywa wysyłane do innej klasy, niekoniecznie równoległej wiekowo, a nawet pozostaje w klasie w czasie lekcji religii, aby mogło odrabiać zadania domowe. W analizowanych wypowiedziach zaznacza się, że jest to wyraźny sygnał do rodziców ze strony szkoły, że ich dziecko nie mieści się w „ogólnie przyjętej” normie, co może prowadzić do stygmatyzacji społecznej, np.:

Mój młodszy syn chodzi do 6 klasy. Religię mają w środku. Wybieram się w tej sprawie do szkoły bo on siedzi na korytarzu. Wychowawczyni tłumaczy się że nie ma sali. Szukam podstawy prawnej wg której mają jemu zapewnić podczas tej godziny opiekę, dołączyć do innej klasy lub zmienić plan przesuwając religię na krańcowe godziny lekcyjne (R, 2,6).

Moje 4letnie dziecię też nie chodzi na religię... ale jak wczoraj się dowiedziałam mimo iż jest podpisana deklaracja nieuczęszczania na religię, J. w czasie przeznaczonym na ten przedmiot przebywa $w$ tym samym pomieszczeniu. $Z$ różnicą taką że dzieci na dywanie z katechetką a ona (+ jeszcze jedno dziecko) przy stoliku. Wychowawczyni powiedziała że nie może jej w tym czasie przekazać do grupy obok - ponieważ ma je pod swoją opieką, jest za nie odpowiedzialna... byłam w szoku. Jutro idę do dyrektorki zalatwić to (R, 2,9).

Moja córka dzisiaj mi powiedziała, że na religii ksiądz powiedzial do klasy, że skoro moja córka nie chodzi na religię to nie znajdzie sobie męża, bo nikt nie będzie jej chcial. Dzieciaki jej to powtórzyły. Mojej córki to w sumie specjalnie nie obeszło, ale czuję, że nie powinnam tego tak zostawiać $(\mathrm{R}, 2,12)$.

Kategoria trzecia: obecny nieobecny. Innym trudnym problemem zauważonym w analizowanych postach są kwestie organizacyjne - dziennik elektroniczny i nieobecności. Okazuje się, że brak deklaracji nieuczestnictwa (tej niezgodnej z prawem) może skutkować naliczaniem nieusprawiedliwionych nieobecności, które następnie wpływają na ocenę z zachowania. $\mathrm{Z}$ kolei dziennik elektroniczny, czyli de facto zbiór danych osobowych, jest udostępniany katechetom również w wypadku dzieci nieuczęszczających na religię - tu w wypowiedziach ujawniają się duże obawy o bezpieczeństwo tych danych i sposób ich wykorzystania do np. społecznego napiętnowania:

Taką odpowiedź dostałam od nauczycielki w sprawie nieobecności na religii:

„Dzień dobry, odpowiedź od pani dyrektor: Jakiekolwiek oznaczenie musi być - gdyż dziecko w czasie pobytu w szkole jest zaopiekowane. W bibliotece znajduje się lista dzieci, które nie uczęszczają na religię i nauczyciel bibliotekarz oznacza ich obecność. Nie może być inaczej, gdyż dziecko nie może opuścić budynku szkoły w trakcie zajęć. Uczeń może być zwolniony do domu z ostatniej (lub pierwszej) godziny, na której jest religia - za pisemną zgodą rodziców. Nie ma jednak możliwości dostosowania planu tak, aby religia 
zawsze byla na pierwszej lub ostatniej godzinie lekcyjnej. W razie wątpliwości proszę o kontakt z panią dyrektor".

I co Wy na to?... czuję, że jak sama coś naskrobię, to będzie to niemiłe... (R, 3,8).

Witam, Dzisiaj w Librusie pojawiły mi się nieobecności u moich dzieci za wczorajszy dzień. Dzieci mi powiedziały że muszę im napisać usprawiedliwienie, mimo tego że była msza potem akademia a lekcje się NIE odbyły (R, 3,10).

Kategoria czwarta: czy to matematyka czy religia? Kolejny pojawiający się wątek, który wyłania się z analizowanych wypowiedzi, to zastępstwa na lekcjach obowiązkowych wykonywane przez katechetów lub osoby duchowne, którzy na danej lekcji przeprowadzają katechezę. Według obowiązujących przepisów nauczyciel religii, o ile nie jest również nauczycielem innego przedmiotu i nie ma ku temu odpowiedniego przygotowania pedagogicznego, nie może być przez dyrektora skierowany na zastępstwo na lekcję obowiązkową. Tymczasem opisywana w postach rzeczywistość szkolna jest inna niż ta określona przepisami prawa:

Klasa mojej córki (5 klasa) ma dziś religię, po której powinien być w-f, niestety pan się rozchorował i będzie zastępstwo w postaci religii, dodatkowo katechetka zabiera podobno dzieci na różaniec - chyba do kościoła - córka nie jest pewna... proszę utwierdzić mnie w przekonaniu zanim napiszę pismo - nie mają prawa organizować religii w formie zastępstwa? (R, 4,2).

Wczoraj na zastępstwo na matematykę przyszedł ksiądz i puścił dzieciom film „Bóg nie umarł”. Chyba nie muszę pisać, że jestem wściekła. Co mogę zrobić w tej sytuacji? Czy ksiądz może mieć zastępstwa na innych lekcjach? $(\mathrm{R}, 4,6)$.

Kategoria piąta: wszystko, co szkolne, może być religijne. Jeszcze innym drażliwym tematem, który pojawia się w wypowiedziach, są wydarzenia szkolne, które mają aspekty religijne, takie jak jasełka, uroczyste apele, obchody uroczystości szkolnych, pasowanie na ucznia w trakcie mszy - to tylko część z przytaczanych przykładów. W niektórych postach pojawiają się wypowiedzi, w których rodzice akceptują takie praktyki, ponieważ są one uznane za część kultury polskiego społeczeństwa, przeważa jednak pogląd, że jest to dalszy etap indoktrynacji religijnej:

Czy taki zapis w statucie szkoły nie narusza Konstytucji?

„2. Do najważniejszych uroczystości tworzących ceremoniał szkolny zaliczamy: (...)

6) uroczyste msze św." (R, 5,8).

Kurczę, myślałam, że szkoła mojego Młodego z tych normalnych, w klasach nie ma krzyży, a gazetka religijna jest ale niewielka i to na 1 piętrze - ujdzie w tłoku. A jednak... W piątek 8 czerwca szkoła obchodzi 60-cio lecie. I taką właśnie wiadomość dostałam: 
„Drodzy uczniowie. W najbliższy czwartek 7 czerwca do szkoły przychodzimy ubrani w strój galowy, ponieważ na trzeciej lekcji wychodzimy do kościoła na msze z okazji 60-lecia szkoły. W tym czasie uczniowie, którzy nie uczęszczają na religie, przebywają w świetlicy. Piątek 8 czerwca jest dniem wolnym, czyli uczniowie nie przychodzą do szkoły".

No krew mnie zalała. Nie wiem czy pisać z interwencją. Wiem, że niczego nie odkręcę. Młody oczywiście zostanie w domu. I jakoś czuję potrzebę, żeby zaznaczyć że ta msza to nie na miejscu jest. I że pachnie wykluczeniem uczniów niechodzących na religię $\mathrm{z}$ obchodów 60-cio lecia szkoły $(\mathrm{R}, 5,9)$.

Kategoria szósta: szkoła jako miejsce sacrum. Ostatnim tu omawianym wątkiem pojawiającym się w wypowiedziach badanych rodziców są wydarzenia religijne, które formalnie są organizowane przez wspólnotę religijną, ale w praktyce w ich organizację zaangażowana jest szkoła, co jest zgodne z wytycznymi Dyrektorium Katechetycznego (2001) zalecającymi, aby proboszczowie rozwijali współpracę szkoły i parafii. Do wydarzeń tych należą m.in. spowiedź na sali gimnastycznej z okazji rekolekcji, adwentu, wielkiego postu, organizacja pielgrzymek szkolnych oraz wyjazdów do miejsc kultu. Budynek szkoły staje się wówczas miejscem, w którym nie tylko naucza się religii, lecz wręcz sam staje się świątynią. Wówczas dzieci niereligijnych rodziców stają się dla szkoły „kłopotem”, z którym nie wiadomo, co począć, np. dzieci są zwalniane z lekcji, ale także zdarza się, że ani one, ani ich rodzice nie są pytani o zgodę na zabranie do kościoła:

Wklejam link do pisma, jakie wysłałam do szkoły, gdy kazano mi usprawiedliwić nieobecność córki na peregrynacji obrazu w Kościele. To był dzień, kiedy zamiast lekcji, cała szkoła musiała iść na specjalną mszę do Kościoła. Może będzie dla kogoś inspiracją $(R, 6,2)$.

„20.12 (czwartek) o godz. 13.30 odbędzie się spotkanie wigilijne w naszej klasie. Dzieci, które nie uczęszczają na religie będą mogły w tym czasie przejść do sąsiedniej klasy. Prosimy Państwa o pomoc w zorganizowaniu poczęstunku. Pozdrawiamy serdecznie, Wychowawczynie 0a"

Czy ktoś wystosowal pismo do dyrekcji w takiej sprawie? $(\mathrm{R}, 6,12)$.

U nas hit! Relikwie św. St. Kostki w szkole! Na godziny podzielona adoracja. Nawet przedszkola nie ominęli! (R, 6,13).

Szkolno-religijne praktyki realizowane przez dyrektorów i nauczycieli przy współpracy kapłanów i katechetów są przez niereligijnych rodziców traktowane jako antywolnościowe, dyskryminujące, stygmatyzujące, niezgodne z prawem, a czasem wręcz sprzeczne ze zdrowym rozsądkiem. Najbardziej jednak widocznym w analizowanych wypowiedziach doświadczeniem jest zdziwienie tym, że edukacja, która powinna być oraz postulatywnie jest centralnym miejscem kształtowania się porządku egalitarnego w kwestiach światopoglądowych, staje się przestrzenią dla postaw oraz języka, które z tak rozumianą 
równością nie mają wiele lub zgoła nic wspólnego, a raczej jest przykładem braku szacunku dla odmienności oraz dyskryminacji dzieci z rodzin niereligijnych. Tym bardziej że wskazywane trudności mają charakter powtarzalny i uporczywy, choć mogą przebiegać nieco inaczej w konkretnym kontekście. Pokazuje to, moim zdaniem, pewien automatyzm polskiej szkoły w myśleniu o odmienności, który zdradza „nawykową nietolerancję” wobec osób, które nie należą do grupy dominującej.

Odpowiadając na drugie pytanie badawcze, na podstawie wypowiedzi należy wskazać, że badani rodzice nie chcą być wyłącznie ofiarą takiej sytuacji. Najpowszechniejszą strategią radzenia sobie przez rodziców z niesprawiedliwymi i przykrymi dla nich przypadkami dyskryminacji (w kontakcie $\mathrm{z}$ instytucją) oraz stygmatyzacji (w kontakcie ich samych oraz ich dzieci z konkretnymi nauczycielami) jest aktywna chęć przezwyciężenia doświadczanych problemów. Badane wypowiedzi dosyć jasno wskazują na chęć zmiany przez rodziców tych niewygodnych dla nich i ich dzieci okoliczności, a w tym celu czerpią oni często z potencjału, którym dysponuje grupa. Na jakie więc strategie radzenia sobie ze szkolnymi praktykami określanymi jako nieprzyjazne wskazują badane wypowiedzi? Po pierwsze posty są rodzajem wymiany w grupie i służą problematyzacji rzeczywistości (refleksyjności) w celu określenia przez autora siebie podmiotem praw - odczucie dyskomfortu i niewłaściwości opisywanych sytuacji (problemów) skłania do podjęcia rozważań na temat własnych interesów i możliwości ich realizacji, odsłania różnice w obrębie pola społecznego, który jest wspólny w innych obszarach (zrozumienie własnej inności, odmienności, opatrzonej jednocześnie etykietą „gorszości”). Refleksyjność badanych rodziców oznacza umiejętność rozpoznania zachodzących zdarzeń i racjonalizację własnego działania w swoim, często niepowtarzalnym kontekście, co pozwala odpowiedzieć na pytanie: czego chcę (Giddens 2003: 17).

Drugą wyróżnioną przeze mnie strategią jest mówienie prawdy, rozumiane jako odwoływanie się do stanu faktycznego, do tego, jak jest. Służy temu przede wszystkim wymiana informacji między członkami grupy na temat aktualnego stanu prawnego (w postaci linków do określonych informacji, plików ze wzorami pism, aktów prawnych regulujących status lekcji religii w szkołach). Wymiana taka ma przeciwdziałać przyjmowaniu statusu homo religiosus jako domyślnej kondycji człowieka, a w sferze codziennych kontaktów z instytucją oznacza wymuszenie respektowania faktycznego stanu prawnego poprzez uzbrajanie się w narzędzia do osiągania celów. Nieodzowną częścią strategii mówienia prawdy są porady, jak wykorzystać dostępne narzędzia, a także opisy indywidualnych przypadków jako przykładów niepoddawania się wszechobecnemu konformizmowi. W konsekwencji nabycie umiejętności zarządzania stanem faktycznym (prawdą) oznacza dla wielu badanych rodziców emancypację, czyli wyjście z pozycji podporządkowanej ku podmiotowej (Foucault 1997: 295-296).

Trzecią strategią, którą udało mi się zidentyfikować w badanych wypowiedziach, jest wsparcie rozumiane jako grupowe działanie pomocowe mające na celu dalszą stymulację refleksyjności oraz troskę o siebie i innych (Sęk, Cieślak 2006). Oprócz omówionego wsparcia merytorycznego badana grupa oferuje swoim członkom zarówno wsparcie 
emocjonalne, jak i aksjologiczne. To pierwsze polega przede wszystkim na podkreślaniu wspólności problemów w chwilach zwątpienia w sens własnych działań. Takie wyrażenia-reakcje, jak „nie jesteś sama”, „trzymamy kciuki”, ,dasz radę”, mimo że z pozoru banalne i nadużywane, budują atmosferę zaufania we własne siły i słuszność wyznaczonych celów oraz są dowodem troski - sprawiają, że indywidualne działania rodzica znajdują oparcie w doświadczeniach innych osób. Jednocześnie wsparcie takie pozwala ostudzić silne negatywne emocje niejednokrotnie pojawiające się w przytaczanych wypowiedziach. Z kolei wsparcie aksjologiczne oznacza podkreślanie w sytuacjach kryzysu, że indywidualne działania przeciw dyskryminacji lub stygmatyzacji są warte tego, aby je podejmować, ponieważ same w sobie są ważne i cenne nie tylko z perspektywy podmiotu stawiającego opór, lecz również z perspektywy „sprawy”, czyli większego dobra (Foucault 2013).

Podsumowując, należy podkreślić, że mimo deklarowanego w przepisach polskiego prawa rozdziału Kościoła od państwa publiczna instytucja polskiej szkoły w wielu wypadkach nie respektuje tego rozdziału. Badane wypowiedzi wskazują na silne powiązania między instytucjami religijnymi a strukturami szkoły. Wskazują także, że ciągle dla szkoły domyślną postawą wobec religii są postawa homo religiosus i imperatyw wiary. Wyłonione kategorie pokazują, na jak wielu obszarach funkcjonowania szkoły powiązania te są obecne. To zaś prowadzi do ujawniania się w wypowiedziach różnych niepokojów i lęków o sytuację dziecka, swoją jako rodzica, a także szkoły. Poczynione analizy uwidaczniają jednocześnie, że dla badanych religia jest arbitralnie narzuconą ideologią, której - jako osoby niereligijne - powinny się przeciwstawić właśnie ze względu na dobro dziecka i dobro szkoły jako instytucji kształcącej i wychowującej. Rzadko bowiem w wypowiedziach zdarzają się strategie ucieczkowe (np. przeniesienie do innej szkoły), dominuje raczej bunt jako forma ekspresji niezadowolenia $\mathrm{z}$ obecnej sytuacji. Jest to tym trudniejsze, ponieważ są to sytuacje codzienne, gdyż rzadko zdarza się, że wywalczone rozwiązanie jest respektowane przez kolejnych funkcjonariuszy szkoły lub religii albo w kolejnych latach edukacji dzieci. Choć badane posty często wskazują na samodzielne zmagania rodziców z napotkanymi trudnościami, widoczne jest jednak szeroko rozumiane wsparcie ze strony innych użytkowników grupy. Zapewnia ono pomoc i zasoby, które sprzyjają radzeniu sobie z tą trudną dla niereligijnych rodziców sytuacją.

\section{Literatura}

Babicka-Wirkus A. (2019), Kultury oporu w szkole. Działania-motywacje-przestrzeń. Warszawa, Wolters Kluwer.

Berger P.L. (2005), Święty baldachim: elementy socjologicznej teorii religii. Kraków, Zakład Wydawniczy Nomos.

Blackford R., Schüklenk U. (2014), 50 mitów o ateizmie. Stare Groszki, Wydawnictwo CiS.

Boguszewski R. (2012), Religijność i moralność w spoteczeństwie polskim: zależność czy autonomia? Studium socjologiczne. Torun, Wydawnictwo Adam Marszałek.

Comte-Sponville A. (2011), Duchowość ateistyczna. Wprowadzenie do duchowości bez Boga. Warszawa, Wydawnictwo Czarna Owca. 
Dyrektorium Katechetyczne Kościoła katolickiego w Polsce (2001). Warszawa, Konferencja Episkopatu Polski.

Eliade M. (1997), Historia wierzeń i idei religijnych. T. 1. Warszawa, Instytut Wydawniczy PAX.

Eliade M. (2000), Traktat o historii religii. Warszawa, Wydawnictwo KR.

Foucault M. (1997), Ethics. Subjectivity and Truth. New York, The New York Press.

Foucault M. (2013), Etyka troski o siebie jako praktyka wolności. W: B. Błesznowski, K.M. Jaksender, K. Matuszewski (red.), Kim pan jest, profesorze Foucault? Debaty, rozmowy, polemiki. Kraków, Wydawnictwo Eperons-Ostrogi.

Giddens A. (2003), Stanowienie społeczeństwa. Zarys teorii strukturacji. Poznań, Zysk i S-ka.

Grabowska M. (2018), Bóg a sprawa polska: poza granicami teorii sekularyzacji. Warszawa, Wydawnictwo Naukowe Scholar.

Hervieu-Léger D. (2007), Religia jako pamięć. Kraków, Zakład Wydawniczy Nomos.

Majcherek J.A. (2015), Bóg bez znaczenia. Stare Groszki, Wydawnictwo CiS.

Marzęcki J. (1999), Systemy religijno-filozoficzne Wschodu: historia - metafizyka - etyka. Warszawa, Wydawnictwo Naukowe Scholar.

Mendel M. (2000), Partnerstwo rodziny, szkoły, gminy. Toruń, Wydawnictwo Adam Marszałek.

Obirek S. (2015), Polak katolik? Stare Groszki, Wydawnictwo CiS.

Piekot T. (2006), Dyskurs polskich wiadomości prasowych. Kraków, Wydawnictwo Universitas.

Sęk H., Cieślak R. (2006), Wsparcie społeczne, stres i zdrowie. Warszawa, Wydawnictwo Naukowe PWN.

Sochoń J. (1999), Kościół wobec ateizmu (kilka uogólnień). „Warszawskie Studia Teologiczne”, 12.

Szczepański J. (1971), Odmiany czasu teraźniejszego. Warszawa, Książka i Wiedza.

Tyrała R. (2014), Bez Boga na co dzień: socjologia ateizmu i niewiary. Kraków, Zakład Wydawniczy Nomos.

Wach J. (1961), Socjologia religii. Warszawa, PWN.

Zwoliński A. (2018), Ateizm i jego wspótczesne oblicza. Poznań, Wydawnictwo Monumen. 